\title{
The relationship between prophetic preaching and performing the gift of prophecy in South Africa
}

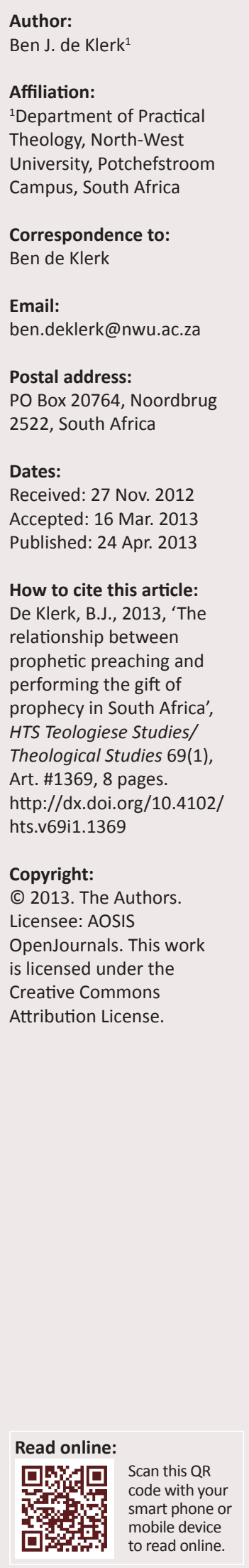

The goal of this article is to investigate the relationship between the liturgy of the worship service, where prophetic preaching is delivered, and the liturgy of life, where the gift of prophecy must be put into practice. In what way could the 'prophets' be equipped to become practitioners of the gift of prophecy? A short description is given of what is understood by prophetic preaching and the gift of prophecy in an effort to determine the relationship between these concepts. In a brief summary, burning questions in church life and in the South African society are addressed: in church life, the questions of extreme conservatism and extreme liberalism are scrutinised and in the South African society, corruption and inequality are investigated. In conclusion, a few guidelines are given for putting the gift of prophecy into practice in the liturgy of life.

\section{Introduction}

Marvin McMickle, an African American homiletition, wrote a book with the title, Where have all the prophets gone? (2006). He comments about his fellow preachers and himself, that 'many of us have sold out the God of biblical justice for a lesser god and, in doing so, have blunted or silenced the prophetic voice of the pulpit' (McMickle 2006:5). We may ask the following question in this regard: Although the prophetic voice of the preacher might be spoken powerfully from the pulpit, would his voice be heard by the people who need to hear it, but who are outside the worship service? To put it in another way: Is it possible that the message brought by a prophetic voice is left behind in the church building by the hearers? Or could the hearers be missionaries who are sent out to carry the prophetic message of God into the world of God?

In this article, two issues are investigated: the first is the question of the relationship between prophetic preaching by preachers and the gift of prophecy of those who are hearing the prophetic preaching. The second is the question about the way in which the prophetic message could be brought to people outside the congregation, specifically in the South African context. What could hearers contribute to carrying out the prophetic message by their attitudes, words, deeds and actions?

The work plan that will be followed is firstly to investigate the relationship between the liturgy of the worship service, in which the prophetic preaching is delivered, and the liturgy of life, in which the gift of prophecy must be put into practice or performed. The next step will be to discover how the 'prophets' may be equipped to become practitioners of the gift of prophecy. This will be followed by a short description of what is understood by prophetic preaching and the gift of prophecy in an effort to determine the relationship between the two concepts. In a brief summary, burning questions in church life and in the South African society are addressed. In church life, the questions of extreme conservatism and extreme liberalism are scrutinised. In the South African society, corruption and inequality are investigated. In conclusion, a few guidelines are given for putting the gift of prophecy into practice in the liturgy of life.

\section{Worship service as 'gathering and sending'}

To Calvin liturgy was not restricted to an isolated domain, but he regarded it as flowing over into the entire life of God's children in the world. Thus, according to Calvin's vision, liturgy and ethics belong together, just as acts of serving the Lord in the assembly on Sundays and acts of serving Him in our homes and at work during the week belong together (Sederhuis 2009:412). Struggling with daily faltering and shortcomings, believers search for forgiveness and consolation in the worship service and the worship service prompts them to sanctify their lives and work. The purpose of the liturgy is to glorify God, also when a daily liturgy is performed in the world (Fenwick \& Spinks 1995:11). The strength and energy gained in meeting God in the liturgy of the assembly flows over into everyday life (Bridges 1998:240). 
In the workplace and in society, when believers become more aware of and experience God's presence at a deeper level, they bring the world before God, but they also bring God's grace to the world, amongst others in their prayers. The worship service may never be a kind of escape from the world and must not be lopsidedly spiritualised, but it must have the function of sending congregants out here and now in order to glorify God (Piper 2007:24). The liturgy of the assembly is thus continued in everyday life amongst people who have not participated in it, who do not know it and who harbour all kinds of wrong ideas about it.

We have referred to the interaction between the liturgy of the assembly and the liturgy of life in terms of gathering and going out, receiving and giving, hearing and proclaiming, praying and working, inhaling and exhaling - the systolic and diastolic function of the pumping heart in liturgy. The relation between the liturgy of the assembly and the liturgy of the world may be compared to the relation between the minor and the major blood circulation systems of the human body. The blood is purified and renewed by the minor blood circulation system, and by the major blood circulation system it is transported to all organs and limbs right down to the capillaries. Participants in the worship service go out to be like yeast, salt and light in the world. Then they come back again like the farmer gathering his harvest. The worship service of life flows forth from the nature of the assembly, and the church can never isolate itself from life and the needs of the world. Worship that does not have a bearing on everyday life is unreal, out of touch with life, feeble and misses its true purpose. The worship service actually wants to equip us for life, for daily service to God and his kingdom, for sanctifying our lives and bearing witness to the grace of God in the world. It concerns the glory of God and we must search for his glory within the milieu and the force field of our daily lives where we can have a benedictory effect using our spiritual strengths.

If the act of gathering denotes a definite entrance (introïtus) into the space and time of the congregational liturgy, the believers have to be prepared to go back across the boundary of this space and time into the world (space) and week (time) that are waiting for them. It is therefore heart-rending that in many cases the liturgist signals to the participants in the worship service, 'everything is finished now'. Alternatively the message is, 'the worship service has ended'. Instead, the send-off blessing should actually announce the beginning of the worship service of life. Hughes (2003) quotes the words of a congregant, Paul Pruyser, a pastoral psychologist, in this regard:

Over the years, in attending worship services, I had gradually become accustomed to ministers terminating their services with a rushed and hardly audible benediction. When the benediction was pronounced from the pulpit, audibly and visibly, the spectacle for the beholders was often little more than the slovenly gesture, consisting of only one arm raised half-heartedly on only halfway up, against the force of gravity to which that poor limb would quickly succumb again. (p. 159)
In the act of sending off there are two movements: the believers are sent out of the gathering (service) and into the world. The German term Entlassung emphasises the element of sending out. The believers might wish to stay a little longer in the warmth of the assembly, and they might want to listen and sing more, but they have to get out of the safe space of the communion of believers (Van Leeuen 1998:257). They must hold onto the gospel they have heard, experienced and shared. Now they must carry it into the world.

The scriptural foundation for the congregation being sent out by the send-off blessing is found in the blessing at Jesus' Ascension, which is directly connected to his Great Commission to make disciples and to be witnesses in the world. For this reason, Luke 24 can be described as a pivotal point not only for future promises of the blessing in the Name of Jesus and his Father, but also in connecting the blessing to evangelisation. The disciples having received Jesus' blessing in their capacity as representatives of the church, went out and God put them in the way of all to whom they had to proclaim the blessing:

What was their response? In keeping with the pattern throughout the scriptures, they received God's Blessing (i.e. Jesus), and became a blessing to others through the spreading of the good news. (Kapic 2005:252)

On the ground of this reasoning, there can be no doubt that the blessing flows forth from God's grace and that he himself pours the blessing into the hearts of his followers. The Great High Priest did not only come to pronounce the blessing, but he became the Blessing himself:

He redeemed us to worship Him, and as redeemed people, we are called to be a blessing to the nations. Mission flows from worship, not vice-versa. Worship is the fuel and the goal of missions. (Hall 2001:1)

Because the blessing comes from God as the source, it must of necessity have a powerful effect on those who are blessed. God endows the capacity of promising the blessing to his authorised servants; therefore, they pronounce the blessing in words prescribed by God himself, and they do so with authority. The pronouncement of the blessing has the same authority as the scripture reading in the liturgy.

This section is concluded by reaffirming that the blessing pronounced by Jesus at his Ascension is directly connected to the commission to evangelise:

'Mission' (i.e. people's glad acceptance of their responsibilities as disciples) is not out of sight in the section (the very name 'Sending' in its allusion to 'apostolicity' ensures this). But without empowerment - and the grace of God - given in 'blessing', this can only be a variously resigned or strident commitment to philanthropic humanism. Blessing is thus the sine qua non of mission. (Hughes 2003:168)

The liturgy of the worship service and the liturgy of everyday life are drawn together in the sending-away blessing. This liturgical act sends the hearers of the prophetic preaching into their world to put into practice the gift of prophecy. 
Apart from the fact that participants in the worship service are equipped didactically by preaching, they are also prepared for their task as 'prophets' by all the elements of the worship liturgy. Before discussing prophetic preaching in 'Brief description of prophetic preaching', the following elements will be discussed briefly in "Equipping the "prophets" in the worship service', that is, doxology, koinonia, diakonia and the celebration of the Lord's Supper. Offerings of love that go hand in hand with the Lord's Supper will also be touched upon.

\section{Equipping the 'prophets' in the worship service}

Doxology not only includes utterances and songs of praise, but also songs and prayers of lament and of confession of guilt. The very nature of doxology makes it a powerful instrument in equipping worship service participants. In performing these actions, participants acknowledge that they live in a broken world and they mourn the devastating results of living consciously in sin. On the other hand, they also rejoice in the good news that they are part of God's new world, which is breaking through at present. In doxology, worship participants sing hymns of lament for the broken world in which they live, but they also sing songs of hope in view of the new world to come. ${ }^{1}$

Equipping participants for putting the gift of prophecy into practice in the world also takes place in the worship service by experiencing koinonia. Koinonia takes the shape of friendliness, forgiveness and deeds of love towards one another. The diakonia in the worship service consists of the love offering and other concrete gifts to those in need. This diakonia educates the participants in the worship service to accompany their prophetic testimony with the love of Christ by performing practical deeds of love to those in need in this world.

The celebration of the Lord's Supper is a visual learning experience to put the gift of prophecy into practice. Other symbols may also serve to sensitise the prophetic memory. Calvin indicated three functions of the Holy Communion: it confirms faith, it generates gratitude and it encourages joint love (Gerrish 1993:125). The question is whether this third function is accounted for in the current practice of the Communion celebration of churches and in the effect of the Holy Communion on daily life. The origin of the collection of the offering in the worship service is found in sharing gifts (natural food gifts) at the agape meals of the first congregation. In this way, the congregation celebrated communion with the Lord and each other. The food that was left over went to the poor, the sick and the prisoners. The Holy Communion abounded in diaconal worship by offering services. In answer to God's mercy (compassion), it was all about the offering of the self ( $\operatorname{Rm~12:1):~}$

De eucharistie als maaltijd roept heel de werklijkheid op van het materiële, het lichamelijke, het economische en van de sociale gewoonten en gebruiken die onvermijdelijk in alle culturen het

1.It will be shown in 'Brief description of prophetic preaching' of this article that these contrasting sensations are characteristic of the dialectical nature of prophecy, namely that it criticises and energises (Brueggemann 2001). eten en drinken begeleiden. [The Holy Communion as a meal calls for the reality of the material, the physical, the economic and social habits and customs that inevitably guides eating and drinking in all cultures.] (Lukken 1996:25, [author's own translation])

From the New Testament and the earliest writings, it can be derived that the Christians brought a variety of gifts in natura to the worship service. They were originally used for the meals of love, but also for taking care of the needy. It can be assumed that these gifts were also used for celebrating the Holy Communion. What was left was distributed among the needy. From the 3rd century onwards, bringing gifts was clearly included in the celebration of the Holy Communion. Since the 11th century, bringing gifts in natura was replaced by monetary offerings (Wepener \& Cilliers 2004:368). Only having a meal and calling it the 'Holy Communion' is not enough - believers must know what they do and why they do it (1 Cor 11:28), and do it in the correct manner. This type of meal, a meal of love, was a way of taking care of the poor. Since the rich brought more than the poor did, and they all ate together, a kind of equality was created (2 Cor 8:14).

The participants in the worship service are equipped by prophetic preaching in particular, which will be discussed in the next section.

\section{Brief description of prophetic preaching}

In his well known book, The Prophetic Imagination (2001), Walter Brueggemann characterises prophetic preaching as dialectic preaching, because it has the character of criticising and energising (Brueggemann 2001:115). Because the preacher is created in the image of God, and because God's broken image in the human being is revitalised in Christ, and because the preacher (as well as the hearer), is increasingly renewed into the image of Christ (1 Cor 3:18), it is acceptable to speak of prophetic imagination. If the preacher criticises, according to Brueggemann, his preaching has to be full of pathos, accompanied especially by groans and laments. If he wants to energise the hearers, he has to show amazement by uttering doxologies. Brueggemann writes: 'Groans and laments are to dismantle "royal consciousness" and doxologies to sharpen the vision of a new era' (Brueggemann 2001:115). The prophetic preacher's critique will also focus on selfserving and self-securing consciousness, which he calls 'royal consciousness' (Brueggemann 2011:23). At the same time, the prophetic preacher will present the alternative of God's new dispensation with awe. To reach this goal, symbols and metaphoric language may be used. 'The task of prophetic imagination is to cut through the numbness, to penetrate the self deception, so that the God of endings is confessed as Lord' (Brueggemann 2011:45).

Nora Tubbs Tisdale stresses the pastoral aspect of prophetic preaching. In her book, Prophetic Preaching: A Pastoral Approach, she gives an overview of the work of the main scholars on prophetic preaching, and identifies seven hallmarks of prophetic preaching: 
(1) Prophetic preaching is rooted in the Biblical witness.

(2) Prophetic preaching is countercultural and challenges the status quo.

(3) Prophetic preaching is concerned with evils and shortcomings of the present social order and it often concentrates more on corporate and public issues than on individual and personal concerns.

(4) Prophetic preaching requires the preacher to indicate both what things are not of God in the world (criticising) and the new reality God will bring to pass in the future (energising).

(5) Prophetic preaching offers hope of a new day to come and the promise of liberation to God's oppressed people.

(6) Prophetic preaching incites courage in its hearers and empowers them to work to change the social order.

(7) Prophetic proclamation requires of the preacher a heart that breaks because of the things that break God's heart; a passion for justice in the world; the imagination, conviction and courage to speak words of God; humility and honesty in the preaching moment; and a strong reliance on the presence and power of the Holy Spirit. (Tisdale 2010:10)

The above-mentioned description of prophetic preaching is used in this article as an indication of what the characteristics of prophetic preaching are.

\section{Brief description of the gift of prophecy}

The congregation's involvement in preaching reaches beyond the activities of preparation, planning and listening. The congregation should teach each other from the scripture reading and preaching (cf. Heb 5:12; Desilva 2000:212; Long 1995:71), and they should help each other to carry the scripture reading and preaching further into practice. The way in which the congregation carries the preaching further or fails to carry it further could weaken and de-reform preaching. The situation in many congregations could be summarised as follows: the minister of the Word or lecturer leads the congregation in reading, there are prayers, singing, the blessing is received and the congregation goes home then there is a deafening silence. Almost nothing good or bad is heard about the sermon! The sermon is a shot fired on wide plains, not causing an echo or striking a target! The reformed congregation is revealed to be underage, an Ecclesia audience, a church that only listens and remains silent forever. To counteract this devaluation of the preaching events, we now refer to the so-called 16th century prophecy.

The 16th century prophecy is the joint investigation of scripture by congregants with a special gift to apply the preached Word to concrete situations. The experience of Calvin, and later of Voetius and Labadie, was that the gift of prophecy had a bigger influence than the most powerful sermons, and that it promoted the growth of the congregation strongly. Prophecy in the sense of 1 Corinthians 14 is not to forecast future things, but to interpret scripture concretely and to apply the interpretation in consoling and admonishing the congregation (Hall 2003:144).

In evaluating the different gifts and the question what gift would be the most important, the decisive factor is determined by the question: What gift(s) would contribute most to building up or edifying the church? Therefore, the gift of prophecy (i.e. to speak words of edification, encouragement, consolation, and admonishment - 1 Cor 14:3) should be deemed to have much greater value than to speak in languages (Van den Brink, Bette \& Zwiep 2006:359). Prophecy has much more communicative power because of its comprehensibility. This characteristic is fundamental to the church. Indeed, believers must and want to know and execute God's will. Prophecy is the gift to the church in the last days (Ac 2:17).

In the sense of 1 Corinthians 14, a prophet is someone who, by the illumination of the Holy Spirit, has the gift to perceive and proclaim the hand and will of God in the existence and history of the people of God. Prophecy is above all the gift to understand and express what the will of God would be in a concrete, given situation (Ac 11:28; 13:1; 15:32). In practice, it means that the insight of people into the Word of God is used to console and encourage the congregation by revealing God's governance of them (Green 2002:265). By means of prophecy, the helping hand of God is extended directly to the congregants (Cranfield 2004:620; Donfield 2002:193).

The most exalted and eminent gift the Holy Spirit uses to edify the congregation is love. Following love, prophecy is the richest gift (1 Cor 14:1, 3, 5, 18, 19, 22,39). This is the reason why everyone in the congregation should dedicate him- or herself ardently to this gift, and to the reasons why there should be room for developing this gift in congregational life. As the gift of prophecy is closely related to the Holy Spirit and preaching, it should be used within the frame of the worship service (1 Cor 11:17-14:39). As prophecy is applied to build up the congregation, special room must be made for putting the prophetic gift of preaching into practice in the worship service (1 Cor 14:39, cf. Rm 12:6, 7; 1 Tm 5:20).

Anyone who testifies with all his or her heart to the actuality of the Word and pure scriptural preaching in the congregation ought to make sure that opportunities are created for congregants to respond prophetically to the preaching. A confessing response must follow on the Word service. Practically, it means that every member should develop the gift to apply God's Word to different situations of life. Therefore, opportunities have to be created for a 'sermon discussion'. This discussion should deal in particular with the scripture reading. Aspects that have not been touched on in the sermon should receive attention. In this way, the application of what God has said to the congregation could be practically applied to situations in real life. The discussion should not degenerate into a general discussion in which issues are raised and certain convictions are questioned. The agreement should be the following: we are using the gift of applying the Word of God concretely, and therefore members are now going to work together to draw lines from God's Word to situations in everyday life (Kim 2006:149).

It is thus clear that there is a strong relationship between prophetic preaching and the gift of prophecy. The voice of the called preacher and prophet in the worship service will be 
the stimulus to prophets who are leaving the gathering and are sent into everyday life. The voices of those who perform the gift of prophecy in everyday life in discussions, prayers, writings, et cetera, will be brought back into the worship service by the stimulus that the prophetic preacher gets from the testimony of the ones who perform the gift of prophecy.

\section{Summary of the burning questions in the life of churches and in the South African society}

Examples of burning questions that must be addressed by putting into practice the gift of prophesy will now be discussed: two from South African church life and two from South African society.

Two opposite poles in church life that is, extreme conservatism (Mead 2012:255) and borderless liberalism (Yeago 2012:30), cannot be ignored by sincere and honest persons who have received the gift of prophecy.

After 18 years of transformation, South Africa still experiences changes. In these circumstances, some church members see the church as the only anchor in the sea of constant changes and as the agent of keeping the status quo. Everything in the church must stay as it has been for the last 50 years. The effect of this viewpoint is that, on the one hand, the church is focusing only inwards to hold on to its members; on the other hand, the prophetic voice that should be directed at the world is fading away. Congregants who exhibit this demeanour develop a hypercritical attitude towards any other viewpoints and even hostility towards other members of the same church who do not share sentiments similar to their own. Further, congregants with this mindset fill their agenda with objections towards the actions of people who differ from them. In this way, they create a comfort zone that consists of the conviction that all aspects of church life could stay as they have been in the past.

The opposite of this extreme conservatism is also an extreme viewpoint embracing a philosophy of experimental liberty in the church. Its manifestation is usually seen in the liturgical acts of the worship service. It frequently leads to isolation from what is happening in the world and also in immediate society, because the focus is on own piety at the cost of involvement in God's kingdom on earth. Because the focus is one-sidedly on salvation, it leads to a consumer mentality that attracts people to a specific church. Because the main strategy of this liberal viewpoint is praise and worship, personal emotional and spiritual satisfaction and stimulation have blindfolded many people to such an extent that they are unable to see the pain and sorrow of others and to see that their own pain and sorrow is part of this broken world of sin.

In South African society, two burning questions that are frequently raised in discussions are corruption and economic inequality. Prophetic testimony is urgently needed in arguments about these issues.
Corruption is the misuse of public office or a position of authority for private material or social gain at the expense of other people. It represents a departure from ethics, morality, tradition, law and civic virtue (Dassah 2008:38; Mafunisa 2007:261). Corruption manifests itself as bribery, embezzlement, fraud, extortion, abuse of power, nepotism, conflict of interests, insider trading or abuse of privileged information and favouritism (Webb 2009:9). Corruption takes place as an intentional illegal and immoral act of behaviour with the purpose of gaining some kind of advantage. According to the 2009 report of Transparency International (2009:2), South Africa was rated 55th out of 180 countries on the Corruptions Perceptions Index (CPI), with a count of 4.7 on a scale of $1-10$. Corruption is costing South Africans billions of rands a year.

South Africa is the world's most unequal nation, with half the population living in poverty on just $11 \%$ of national income. One measure that indicates major structural problems is the so-called Gini coefficient. Measuring social and economic inequality on a scale of $0-1$ (zero implying no inequality) South Africa gets the highest score in the world at 0.69 for the year 2008. This indicates that in terms of income distribution between rich and poor, the South African population is the most unequal society in the whole world. It is remarkable that levels of inequality are probably no better than they were in the early 1990s, and may even have worsened (Altbeker, Hay \& Bernstein 2010:3). This spells a problem, a severe economic problem for South Africa - poverty (Beukes 2002:2). The World Bank defines poverty as 'the inability to attain a minimal standard of living' (Woolard \& Leibbrandt 2001:42).

\section{Guidelines for performing the gift of prophecy as a liturgical act in the worship service and in the liturgy of life}

The gift of prophecy is a necessary act in the worship service. An example of the various manners in which the liturgical act may be performed are the following: three members of the congregation are given the opportunity to lead the congregation in the gift of prophecy directly after the scripture reading, the explication and application of the prophetic preaching by the preacher. In the process of preparing this liturgical act, the preacher may give the following information to the three members during the week: the different parts of the Bible that will be used in the scripture reading, the pericope that will be used in the sermon, the basic exegesis of the part and also possible applications that he or she will use. Every week, three other members may have the opportunity to lead the congregation in this liturgical act. These members apply reading and preaching the scripture in a prophetic way to their own personal and family life, as well as to the social context that they will confront the coming week. In performing the act of prophecy, the members must keep in mind that criticising and energising are inherent characteristics of the gift of prophecy. 
For both the prophetic preacher and the person who performs the gift of prophecy in the worship service and in the liturgy of life, a heart that breaks with God's breaking heart with a passion for justice (Tisdale 2010:10) is needed. Both preacher and performer of the liturgical act must not only feel pain in their hearts because of all the wrongdoings and sin against God, but also because they want to address the pain and brokenness. The attitude of Nehemiah serves as an outstanding example, because he confessed, 'I confess the sins we Israelites, including myself and my father's house, have committed against you' (Neh 1:6). Both the prophetic preacher and the leader in the gift of prophecy will be entirely dependent on the power of the Holy Spirit in performing these liturgical acts. Through the power of the Spirit, they will be able to show the two important inner strengths of humility and honesty in bringing the prophetic message. Performing the liturgical act of prophecy by congregants will lead to continuous self-examination and self-criticism as one side of the prophetic act, but also to an exciting and inspiring journey to discover a new attitude, a new way of conversation with fellow congregants and a new lifestyle in Christ, as another side of the prophetic act. When these prophets courageously indicate wrong perceptions in church and society, they will do it full of pathos. When they open up new possibilities according to God's will and plan to replace these wrong perceptions, they will do it with amazement. This is also the spirit in which wrong perceptions and sin on the one hand, and new possibilities as an alternative on the other hand, must be handled in the liturgy of life - in respect of both the life of the church and life in society.

It is possible that prophetic critique of the viewpoint that the status quo in the life of the church must be maintained at any cost, will assume the tone of aggressiveness if it is met with an aggressive way of defence. However, in this way, valuable energy is wasted. This energy can rather be used in guiding people to see the exciting possibilities that God gives the church in current times. Performing the gift of prophecy against this heresy will start full of pathos towards persons nurturing the extreme conservative viewpoint. The critique of this viewpoint will be expressed in a spirit of a broken and contrite heart. It will be a lamentation on behalf of the people who subscribe to this viewpoint. It must be emphasised that without a broken heart and sincere confession, people adhering to this wrong viewpoint will not be able to change their attitude according to biblical principles. Having said this, this does not mean that the prophetic testimony will not be strong and clear against a spirit of self-service and own security. Furthermore, it is important that the focus will always be on the wrong viewpoint and not on the personalities of the persons. The sin of self-satisfaction and impatience with and aggression towards others is unacceptable. None of these attitudes is in correspondence with God's will.

In this context, the gift of prophecy may be performed by showing an attitude of love and setting an example by speaking honestly. It is very important to indicate new possibilities in an energising way. Security is not found in the status quo, but in new possibilities that God creates every day. It is discovered in God's plan for his children in an ever-changing world. By introducing the forever-new news of the gospel to society of today, new ways of thinking and acting can be found, especially if accompanied by enduring prayer. Instead of a spirit of aggression towards others, the joy of the prophetic message may be discovered in presenting a vision that God's Spirit also uses the views of people with other viewpoints to open one's eyes to see God's multi-coloured grace.

The prophetical critique of the viewpoint that accepts and inspires radical experimenting in the church's activities, may be less severe, because this viewpoint creates more space for other standpoints. The attitude of direct and honest critique, but full of pathos towards persons, is also necessary in this case. The sin of focussing only on the spirituality of praise and worship and emotional growth of the church, but avoiding testifying in society, must be pointed out. The promise that there will be prosperity in all facets of life, provided that God is praised, must be spelt out as false if mourning about $\sin$ is neglected. In the prophetic testimony, the ultimate joy may be proclaimed to the believer that through the communion with Christ's suffering and death he or she may also embrace Christ's resurrection. It is only possible to follow Christ by learning to cry with the suffering and the needy in this world and to lament the pain of one's own brokenness because of $\sin$. The cry about the brokenness will have the effect of an active involvement in God's new world, which is breaking through into this old broken world.

The members of the church may use different ways to put to practice their gift of prophecy in society. This includes their personal examples and informal conversations, the public press, the Internet's social networks, the combined testimony of a congregation and other church communities, their professional unions and other non-governmental organisations. Using all of these - and perhaps more instruments - it only depends on the burning longing of every individual 'prophet' to put to practice the gift of prophecy by criticising and energising.

The prophetic voice against corruption may tend to criticise from a distance, without identifying with corruption. The 'prophet' must in the first place discover personally in what manner the spirit of corruption has infected his or her mind and sorrowfully confess it. It is not profitable to discuss corruption in South Africa in a sort of disapproving and emotional manner without verifying the facts. The sin of corruption in state and semi-state institutions must be reported to the different keepers of the law. Corruption must be brought into the public domain, because the power of corruption and its continuation is secured by keeping the actions secret. The underlying vice that leads to corruption, namely greed, must be brought into the open. Believing prophets must lament this sin with and on behalf of society (see Is 6:5, where Isaiah identifies himself with the people's sin) because of the devastating effect that corruption has on the entire society, especially on the poor. 
The prophetic testimony should also lead to motivate and energise people, so that they can see new possibilities in this regard. Without the effect of corruption, where billions of rands are disappearing from others such as the state and taxpayers, rectifying social action must be taken. Examples are to create jobs, provide job security and alleviate poverty. The change these initiatives could bring about in the present and future society, especially the creation of jobs for young educated people, could energise the community. A negative spirit that could develop into aggression and hate could be changed into a spirit of co-responsibility for the conditions of life in the country. The deliverance that could be brought about by an attitude of sharing with others, instead of one of greed, is part of the message of the Good News of the gospel. In this way, both facets of the gift of prophecy, namely criticising and energising, will be in balance with each other.

Inequality as a phenomenon and as a reality cannot per se be judged as being unbiblical, because there are differences in contexts and in opportunities, abilities and intelligence, et cetera. However, inequality has also a dark side, a sinful side. In the South African context, inequality is a sin because people in powerful positions become richer and the poor people become poorer. The prophetic voices of God's people cannot remain silent when one group is hurt at the expense of another. Inequality affects people mostly in the areas of economics and education. The first step in performing the gift of prophecy is that the 'prophet' must look inwardly at his or her own attitude towards benefaction in all aspects of his or her life. Did the system of apartheid not firmly establish inequalities that even the 'prophets' gained from at the expense of others? The admission of self-gain through apartheid or other ways entails two acts: contrition and confession of guilt. The 'prophet' will also identify with the pain, sorrow and miseries effected by this system. Putting the gift of prophecy into practice against inequality will focus on greed and the misuse of power to uphold and advance inequality. The sinful way of upholding inequality and the pain that it brings to those who are hurt by it must be disclosed.

In contrast to the phenomenon of inequality and all its disruptive consequences, the prophetic testimony may state the energising and exciting possibilities of breaking down this sort of inequality. God does not differentiate between rich and poor, because they are equal in Christ. In the great commandment, Christ stresses that one should love your neighbour instead of hurting him or her. The energising thought that more jobless people will get decent jobs, can lead to eradicating poverty and social problems associated with poverty. An example of such a problem is young girls who fall pregnant to get social grants in order to survive. God gives better alternatives to viewpoints that tolerate glaring inequality.

\section{Conclusion}

The interaction between prophetic preaching and the gift of prophecy represents a tight relationship. The prophetic word of comfort and encouragement must be heard in the worship service to equip members for their prophetic task in society, and the prophetic voice of criticising and energising is needed in the South African society of today.

\section{Acknowledgements Competing interests}

The author declares that he has no financial or personal relationship(s) which may have inappropriately influenced him in writing this article.

\section{References}

Altbeker, A., Hay, M. \& Bernstein, A., 2010, 'Poverty and inequality. Facts, trends, and hard choices', Proceedings of a Round Table convened by the Centre for Development and Enterprise, The Centre for Development and Enterprise, Johannesburg. (CDE Round Table, 15).

Beukes, P., 2002,'Life before death - socio-economic justice issues and mission. The Economy, Poverty and the Church', in J.J. Kritzinger (ed.), Mission in the new SA, pp. 1-14, Pretoria University, Pretoria.

Bridges, J., 1998, The joy of fearing God, Waterbrook Press, Colorado Springs.

Brueggemann, W., 2001, Prophetic imagination, Fortress Press, Minneapolis.

Brueggemann, W., 2011, The practice of prophetic imagination: Preaching an emancipating word, Augsburg Fortress, Minneapolis, MN. (Kindle Edition).

Calvin, J., 1965, Harmony of the evangelists, Matthew, Mark and Luke, vol. 3, Eerdmans, Grand Rapids.

Calvyn, J., 1991, Instutusie van die Christelike Godsdiens, deel 4, vertl. H.W. Simpson, Calvyn Jubileum Boekefonds, Potchefstroom.

Cranfield, C.E.B., 2004, Romans 9-16: A critical and exegetical commentary, T\&T Clark International, London.

Dassah, M.O., 2008, 'Is there a hole in the bucket? Identifying drivers of public sector corruption, effects and instituting effective combative measures', Journal of Public Administration 43(3.1), 37-62.

Desilva, D.A., 2000, Perseverance in gratitude: A socio-rhetorical commentary on the epistle 'to the Hebrews', Eerdmans, Grand Rapids. PMCid:18822

Donfield, K.P., 2002, Paul, Thessalonica, and Early Chritianity, Eerdmans, Grand Rapids. PMCid:126614

Fenwick, J. \& Spinks, B., 1995, Worship in transition. The liturgical movement in the twentieth century, Continuum, New York.

Gerrish, B.A., 1993, Grace and gratitude. The eucharistic theology of John Calvin, Fortress Press, Minneapolis.

Green, G.L., 2002, The letters to the Corinthians, Apollos, Leicester.

Hall, D., 2001, 'The centrality of worship: Foundational points for a theology for worship and missions', in Mission frontiers: The News and Issue Journal from the U.S. Center org/2001/02/central.htm

Hall, D.R., 2003, The unity of the Corinthian correspondence, T\&T Clark International, London.

Hughes, G., 2003, Worship as meaning. A liturgical theology for the late modernity, University of Cambridge Press, Cambridge. http://dx.doi.org/10.1017/СBO978051 1615481

Kapic, K.M., 2005, 'Receiving Christ priestly benediction: A Biblical historical and theological exploration of Luke 24:50-53', Westminister Theological Journal 67(2), 247-260.

Kim, C.H., 2006, 'Prophetic preaching as social preaching', Evangelical review of theology 30(2), 141-151.

Long, T.G., 1995, Hebrews, T\&T Clark, London. (Interpretation: A Bible commentary for teaching and preaching).

Lukken, G., 1996, 'Inculturatie van de liturgie. Theorie en praktijk', in J. Lamberts (ed.), Liturgie en inculturatie, pp. 15-56, Acco Leuven, Amersfoort.

Mead, W.R., 2012, 'God's country?' in W.R. Mead (ed.), Rethinking religion and world affairs, pp. 247-261, Oxford University Press, New York. http://dx.doi.org/10.1093/ acprof:oso/9780199827978.003.0017

McMickle, M., 2006, Where have all the prophets gone? Reclaiming prophetic preaching in America, Pilgrim Press, Cleveland. PMid:17077828

Mafunisa, M.J., 2007, 'Corruption and service delivery in the public services: The case of Limpopo Province', Journal of Public Administration 42(3), 260-270.

Oskamp, P., 1998, 'Gebeden en gaven' in P. Oskamp \& N. Schuman (eds.), De weg van de Liturgie. Tradities, achtergronden, praktijk, pp. 217-225, Meinema, Zoetemeer.

Piper, J., 2007, The supremacy of God in preaching, Baker Books, Grand Rapids.

Sederhuis, H.J. (ed.), 2009, The Calvin handbook, Eerdmans, Grand Rapids.

Tisdale, L.T., 2010, Prophetic preaching. A pastoral approach, Westminister John Knox Press, Louisville. 
Transparency International 2009, Corruptions Perceptions Index 2009, viewed 21 August 2012, from http://www.transparency.org/layout/set/print/policy_research/serveys/ $\mathrm{cpi} / 2009 /$ results

UNAIDS, 2009, Report on the global AIDS Pandemic, Joint United nations Programme on HIV/Aids, Geneva.

Van den Brink, G., Bette, J.C. \& Zwiep, A.W. 2006, 1 en 2 Corinthiërs: Studiebijbel Nieuwe Testament, Centrum voor Bijbelonderzoek, Veenendal.

Van Leeuen, Th.M., 1998, 'Wegzending en zegen', in P. Oskamp \& N. Schuman (eds.), De weg van de Liturgie. Tradities, achtergronden, praktijk, pp. 257-265, Meinema, Zoetermeer.
Webb, W., 2005, 'Applying the public service anti-corruption strategy in pursuit of accountable South African Public Administration', Journal of Public Administration 40(2), 151-165.

Wepener, C. \& Cilliers, J., 2004, 'In herinnering aan die kinders ... wat aan honger en koue moet sterf. Liturgie in 'n konteks van armoede', Nederduits Gereformeerde Teologiese Tydskrif 45(2), 364-372.

Woolard, I. \& Leibbrandt, M., 2001, 'Measuring poverty in South Africa', in H. Bhorat, M. Leibbrandt, M. Maziya, S. van der Berg \& I. Woolard (eds.), Fighting poverty. Labour markets and inequality in South Africa, pp. 41-73, UCT Press, Cape Town.

Yeago, D.S., 2012, 'Modern but not liberal', First Things 1, 25-31. 